\title{
Parsuna - the first secular representation of the traditional Russian icon
}

\author{
Takushinova Bella ${ }^{1}$ \\ ${ }^{1}$ University of Campania Luigi Vanvitelli, Department of Architecture and Industrial Design
}

Email:takushinovabella@mail.ru

\begin{abstract}
The second half of the 15th century in the Russian Church history marked a strong decline of spiritual life, which naturally found its reflection in the icon painting. The feeling of integrity of an image, its depth were lost. At the same time, the weakening influence of the Orthodox Balkans and the Byzantine Empire gave way to the influence of the Catholic West with its profoundly different principles of religious art.

In this transitional period of the Russian cultural life, characterized by the transformation of the medieval worldview and the formation of new artistic ideals, appeared parsuna (a rough Russian transliteration of the Latin word "persona") - an early secular portrait of a lay person in the iconographic style that represents an important transition in Russia's art history. The first pasruna were painted, most probably, by the iconographers of the Moscow Kremlin Armoury in the 17th century. The painters of these portraits were usually monks that tended to be anonymous, showing a humility.

Although the stylized forms used in parsuna reveal a lack of concern with preserving the actual features of a person, but rather their overall image (special attributes and signatures allow to define represented), it still can be viewed as one of the very first attempts to look at person not only through the rigid iconographic canons, but also through a prism of psychological interpretation. Thus, this transitional image may be concerned as the initial fundamental step on the way to the further introduction fo the European portrait tradition in Russia.

In this study, we would like to consistently trace how parsuna, thanks to its completely new stylistic value, can be considered one of the earliest stages on the way to the secularization of the Russian art in the early 17th century, which led to the separation from the strict iconographic religious canons and, consequently, to the rapprochement with the European art.
\end{abstract}

(C) 2019 The Authors. Published by IEREK press. This is an open access article under the CC BY license (https://creativecommons.org/licenses/by/4.0/).

\section{Keywords}

Icon; parsuna; image; art; Russia; religious; portrait; iconographic; secular;

\section{Historical reference}

One of the most fundamental features of the history of the Russian visual arts is the absence of any kind of profane painting before the end of the 17th century. The previous period was characterized by the absolute domination of the religious painting, the most important branch of which was represented by the Russian icon. Brought in Russia from the Orthodox Byzantium through the baptism of the Kievan Rus', the icon painting entered the reality of the ancient Russian culture around the 9th century, becoming both its spiritual and artistic nucleus for the following years. 
Since the tradition of icon painting was invented long before its introduction in Russia, the Russian icons followed devotedly all the techniques of this ancient Byzantine art: they were typically painted on specially prepared wooden panels with egg tempera. The highly rich decoration was usually executed with the help of gold or silver leaf that was frequently used for halos and background areas (Ahlborn, Beaver-Bricken Espinola, 1991). As time passed, the Russian icons started to count a wide variety of types and styles far beyond anything found elsewhere in the Orthodox world.

The traditional canons of icon painting, jealously guarded for centuries, made this ancient art extremely important to the medieval culture of Russia: realized by a monk-painter an icon reflected a certain impersonality so, notwithstanding the well-known origin of painting itself, the artist remained often absolutely unknown to the customer (since the artist did not intend to glorify himself, it was not deemed necessary to sign an icon); an icon was always faithful to the precisely strict canons which leads to a certain repetition - the more icon is faithful to the canon, the more it is of value.

The main function of icons was to cause deep spiritual feelings, the ability to permeate and absorb the faithful, instead of provoking psychological analysis of paintings. So, being a sort of material window into heaven (because through icon God makes himself visible to us), the icon played the role of the primordial image of the Russian art.

Although many icon painters remained anonymous to the Russian art history, there is still one name of that should be mentioned. One of the most famous and illustrious painters of icons was undoubtedly Andrej Rublev (1360-1430) (Ivanova, Demina, 1966). According to the scientist of iconographic themes Gianluca Busi, the image of Christ the Savior (1410) of Rublev (figure 1), "unanimously recognized as "beautiful" ("This image of Christ embodies the ideal of the Christ of the Russians. Its beauty and strength are typically Russian, and in its whole appearance is finely plotted. We have the image of a God-man able to "succor and pity"), is "the most beautiful icon of Christ that we know, in fact, the balance between iconography and beauty reaches the top in it" (Busi, 2001).

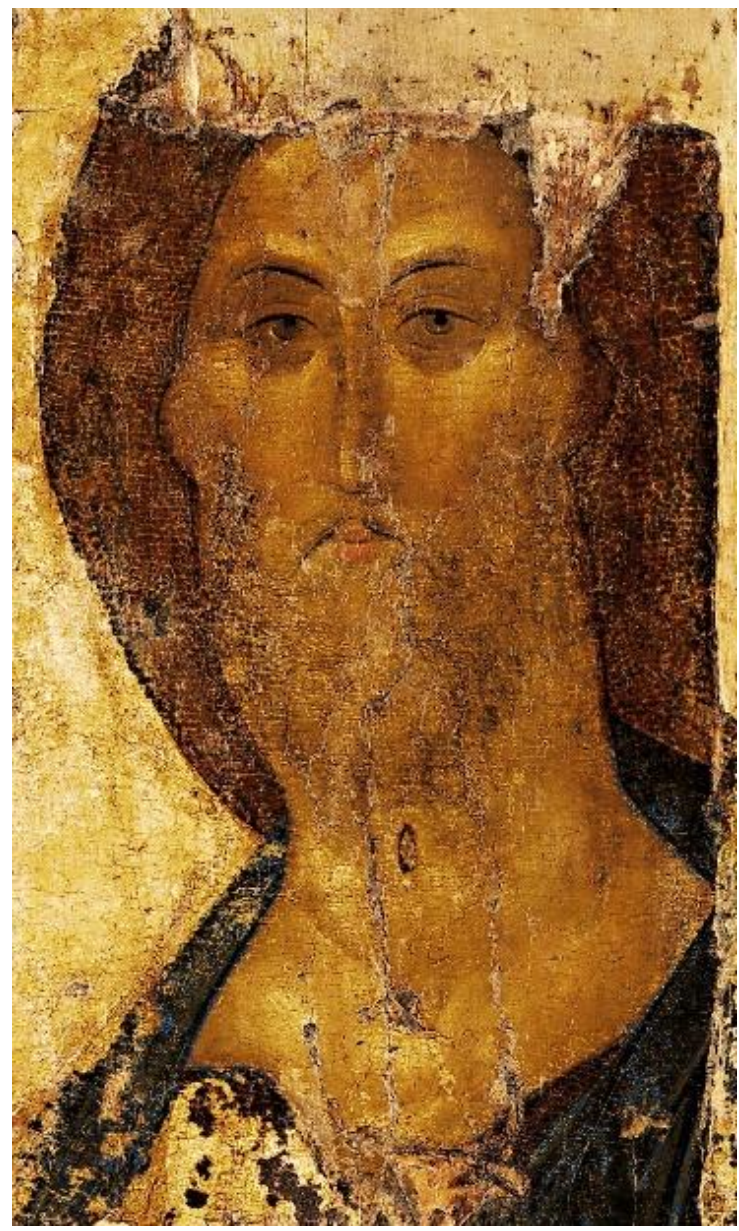

Figure 1. Andrej Rublev, Christ the Redeemer (icon), painted for one of Zvenigorod cathedrals in the 1420s, Tempera on wood Tretyakov Gallery, Moscow 


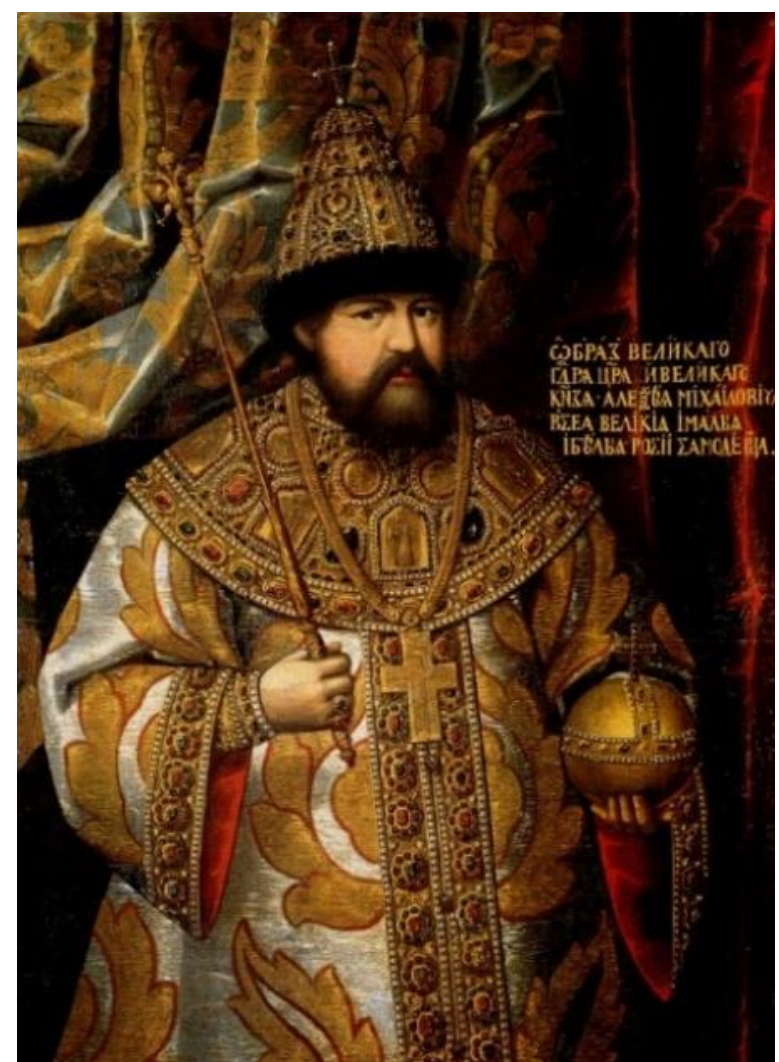

Figure 2. Portrait (parsuna) of Aleksej Mikhailovich «in festive attire» by an unknown artist of the Kremlin Armoury, Oil on canvas, second half of the XVII century, State Historical Museum, Moscow

Until the second half of the $17^{\text {th }}$ century Russia was characterized by an extremely closed external policy. Such a conservative political and cultural position allowed the ancient art of icons to remain the core of the medieval Russian culture.

The splitting of the Russian Orthodox Church into an official church and the Old Believers movement that took place in the second half of the $17^{\text {th }}$ century is generally recognized to be the milestone in the Russian history. Breaking of the resistance of the Church and its complete submission to the power of the State by tsar Aleksej Mikhailovich (16451676), father of the future emperor Peter the Great, defined the further prevalence of the secular orientation in cultural and political development of the State.

Such an important step in the history of the Russian religious life couldn't but lead to significant changes that also found its expression in the artistic field: at the end of the $17^{\text {th }}$ century in the context of the Russian visual arts one of the first steps towards the mundane representation of a real person was finally attempted. Starting from this period, Russia entered the era of secularization of culture through its liberation from the oppressive religious influence (Pivovarov, 2006). Many Russian historians, including Soloviev and Kljuchevskij, defined this time as a "new period" in Russian history. The brightest features of this "new" culture were expressed "[...] in the interest to the personality of the individual, emphasizing the "open" character of the new culture of the $17^{\text {th }}$ century, which had begun to engage in dialogue with the cultures of other countries" (Krasnobaev, 1983).

This new culture began to occupy a firm place in the sphere of visual arts, shifting to background the traditional Russian iconography. Next to the medieval tradition of the icon of the $17^{\text {th }}$ century a clear alienation from medieval art, already for long sclerotized in repetitive forms, revealed itself. The vague traces of realism and linear perspective of the Renaissance appeared, along with the interest in the representation of everyday life, the beauty of nature and the real person: "The figurative system that had been developed in the course of the previous centuries, undergoes changes: the works of art lose their internal integrity, manifesting traits of eclecticism" (Sarab'janov, 1979).

At the beginning of the $17^{\text {th }}$ century in Russia two main artistic directions dominated: the School of iconography of Godunov with its "archaic" style that, formed at the end of the $15^{\text {th }}$ century, followed jealously the traditional iconographic canons; the second direction was represented by the School of miniature painting of the Stroganov which thrived under the patronage of the fabulously rich Stroganov family of merchants in the late $16^{\text {th }}$ and $17^{\text {th }}$ 
century. The realistic elements of the last received further development in the works of the most important masters of that century — the artists of the workshop of the Moscow Kremlin Armoury — the cradle of the most important Russian artists of the $18^{\text {th }}$ century.

The best examples of the Stroganov's School undoubtedly belong to the brush of the head of the Kremlin Armoury, Simon Ushakov (1626-1686), who worked in the second half of the XVII century. In 1667, he wrote an essay entitled A word to the lovers of iconography, in which he expressed his opinions on the objectives of painting, practically breaking with the iconographic tradition of the previous period. In his icons, he destroys the flat surface, thus making tangible the depth of the perspective, identifying, at the same time, the three-dimensionality of human figures, representing them in a surprisingly realistic way (Leonov, 1945).

\section{Appearing of parsuna}

In the $17^{\text {th }}$ century the painters of icons, with some rare exceptions, were still mostly wordless creators and for this reason remained unknown for an increasingly large audience of customer. However, in the second half of the century the growing necessity for artistic autonomy began to establish itself: "The masters of fresco painting have risen to new levels of the vision of the world. Slowly but surely they begin to break free from the prison of the iconographic canons, becoming real creators of the works of art" (Sarab'janov, 1979).

Such radical for that time deviations from the traditional Byzantine canons of icon painting undoubtedly prepared a rich ground for artistic convergence with the Catholic Europe. In this context, it is interesting the appearance of the parsuna (a rough Russian transliteration of the Latin word «persona») - the practice of creating secular portraits according to the traditional style of the icons with stylized depictions of the subjects features. It is thought that parsuna, born in the bowels of what would have entered the history of the Russian art under the name of frjazhskoe pis'mo (literally “the foreign painting”), represents an intermediate step towards the secular portrait tradition.

The term parsuna was introduced in the middle of the XIX century by Ivan Mikhailovich Snegiryov, - one of the first Russian ethnographers who published detailed descriptions of almost every church and monastery in Moscow - as a consequence, apparently, to some scientific misunderstanding, since such a word was not present in the vocabulary of the XVII century, while the word "person" was used in a reference to any portrait image (Ovchinnikova, 1955). With the so-called foreign painting the Russians referred to the iconography and frescoes techniques that distinguished for a realistic representation of the material world. Icons realized according to this technique began to appear in Russia from the second half of the XVII century under the influence of western art.

Since the middle of 17 th century a strong thirst for the completely new vision of man captured minds of the most talented icon painters of the Kremlin Armoury. The first Russian parsuna, most probably, were made by them. Being originally painters of traditional icons, these creators of the first "portraits" tended to be anonymous, expressing thus their complete humility.

According to represented person and technique used, parsuna can be divided tombstone portraits that were usually made of tempera on wood and parsuna painted with oil on canvas representing various monarchs and other notable people.

One of the brilliant examples of these $17^{\text {th }}$-century icon-like portraits of a lay persons is presented by the portrait of the tsar Aleksej Mikhailovich «in festive attire» (figure 2). Even though he was known for his Orthodox piety, Tsar Aleksei Mikhailovich had a broadly ranging curiosity, actively sought Western books and news and displayed an interest in Western culture. Unlike icons which were painted with egg tempera on wood, it is painted in oils on canvas and may well be the earliest Muscovite example of such a painting (Ovchinnikova, 1955).

It is to be noted that usually parsuna, being practically the secularized icon, had a clear moral meaning behind itself: sometimes a parsuna was a kind of posthumous portrait of some notable men. That is why the icon-like stylization of the portrait had as its goal the representation of the prosperous state of the soul of the deceased. The aim of parsuna was definitely not the perfect reflection of physical similarity of the represented person: the portrait likeness was usually transmitted very conditionally, various attributes and signatures that allowed to determine the depicted were frequently used. In this regard, the Russian ancient art specialist Lev Lifshitz observes: "Unlike the "realistic" 
European portrait of the $17^{\text {th }}$ century, the man of parsuna, as well as the one of the icon, does not belong to himself and he is forever excluded from the flow of time. Nevertheless, the man from parsuna doesn't belong to God, since his face addresses to reality" (Lifshitz, 2007).

\section{Conclusions}

These $17^{\text {th }}$ century secular portraits in the iconographic style can be considered an intermediate link between the iconpainting and the traditional secular portrait. Parsuna combined in itself a deep connection with the past, because it still reflected profound heritage of Russian spirituality of the medieval period, and, at the same time, this new style of painting represented a decisive separation from it. The revolutionary character of this type of art reveals itself in the fact that parsuna painters, for the first time in the Russian art history, tended to be realistic in their representations of a person, while the whole Orthodox tradition was extremely against realism, not to mention the depiction of noncanonized people. Such a fresh revision of the traditional religious themes revealed not only the absence of other painting styles in Russia of the $17^{\text {th }}$ century, but rather the fact that, along with the weakening of religious dogmas, the worldview of medieval man began to change dramatically. In a constant search of other forms of expression of a new culture, his consciousness went out on the path of a revolutionary development. A profound change in the perception of the material world, religion and art manifested themselves.

Thus, parsuna was one of the earliest and significant phenomena of the coming $18^{\text {th }}$ century, known for its secular direction. It actually played the role of an artistic bridge between the medieval vision of the ancient Russian art and the European portrait tradition.

\section{References}

Ahlborn, Richard E., Beaver-Bricken Espinola. (1991). V. Russian Copper and Crosses from the Kunz Collection: Castings of Faith. Washington, DC: Smithsonian Institution Press. p. 85.

Busi, G. (2001). La bellezza del Cristo nella tradizione iconografica. Milano, La Bellezza. p. 258- 263.

Ivanova, I., Demina, N. (1966). Rubljov. Milan, Fratelli Fabbri Editori.

Krasnobaev, B.I. (1983). Russkaja kul'tura vtoroj poloviny VII - nachala XIX v. [Russian culture of the second half of the 17th-the beginning of the XIX centuries]. Moskva, Moskovskij Gosudarstvennyj Universitet.

Leonov, A. I. (1945). Simon Ushakov, 1626-1686: russkij hudozhnik XVII veka. [Simon Ushakov, 1626-1686: Russian artist of the XVII century]. Leningrad, Iskusstvo. p. 10

Lifshitz, L.I. (2007). Istorija russkogo iskusstva. Iskusstvo X-XVII vekov. [History of the Russian art. Art of the X-XVII centuries]. Moskva, Trilistnik.

Ovchinnikova, E. S. (2000). Portret v russkom iskusstve XVII veka [Portrait in Russian art of the XVII century]. Moscow, 1955. Translation of Daniel C. Waugh.

Pivovarov, J.S. (2006). Russian politics in its historical and cultural relations. Moscow, «Rossijskaja političeskaja enciclopedia». p. 95-97.

Sarab'janov, D.V. (1989). Istorija rossijskogo i sovetskogo iskusstva [History of Russian and Soviet art]. Moskva, Vysshaja shkola. p. 78-82. 